\title{
Uzaktan Eğitimin Öğretim Elemanları Açısından Değerlendirilmesi: Covid-19 Pandemi Süreci
}

\author{
Seraceddin Levent ZORLUOĞLU \\ Süleyman Demirel Üniversitesi \\ seraceddinzorluoglu@sdu.edu.tr \\ ORCID: 0000-0002-8958-0579 \\ Gamze DEVECIOĞLU \\ Gazi Üniversitesi \\ gamze.dvcgl@gmail.com \\ ORCID: 0000-0003-1508-8730 \\ İdil SAYIN \\ Süleyman Demirel Üniversitesi \\ idilsayin@sdu.edu.tr \\ ORCID: 0000-0001-5546-2673
}

\begin{tabular}{lcr} 
Araştırma Makalesi & DOI: & 10.31592/aeusbed.913291 \\
\hline Geliş Tarihi: 11.04 .2021 & Revize Tarihi: 10.07 .2021 & Kabul Tarihi: 20.10 .2021
\end{tabular}

\section{Atıf Bilgisi}

Zorluoğlu, S. L., Devecioğlu, G. ve Sayın, İ. (2021). Uzaktan Eğitimin öğretim elemanları açısından değerlendirilmesi: Covid-19 Pandemi süreci. Ahi Evran Üniversitesi Sosyal Bilimler Enstitüsü Dergisi, 7(3), 10071025 .

\section{$\ddot{O} \mathbf{z}$}

Bu çalışmada, Koronavirüs 2019 (Covid-19) pandemi sürecinde eğitim fakültesinde görev yapan ve derslerine uzaktan eğitim yoluyla devam eden öğretim elemanlarının uzaktan eğitime yönelik görüşlerinin ortaya konulması amaçlanmıştır. Çalışmanın yöntemi olarak betimsel araştırma yöntemi tercih edilmiştir. Çalışmaya dahil olan öğretim elemanları, seçkisiz olmayan örnekleme yöntemlerinden uygun örnekleme yöntemi ile belirlenmiştir. Öğretim elemanlarından veri toplamak için araştırmacılar tarafından hazırlanan anket kullanılmıştır. Ortaya çıkan verilerin analiz edilmesinde betimsel istatistikten faydalanılmıştır. Çalışmanın sonuçlarına göre; öğretim elemanlarının büyük bir kısmının Adobe Connect programına hakim olduğu, Adobe Connect programının uzaktan eğitimde kullanılmasının kısmen yeterli olduğu, uzaktan eğitimin uygulanmasındaki en büyük engelin altyapı yetersizlikleri olduğu, uzaktan eğitim uygulamasının öğrenci açısından kısmen verimli olduğu, derslerde kullanılan öğretim yöntem ve tekniklerinin çoğunluğunun sözel anlatımdan oluştuğu, uzaktan eğitim ders sürelerinin yeterli olduğu, öğretim elemanlarının öğrencilerle etik ihlaller yaşayabileceklerini düşünmeleri sebebiyle ders içeriklerini paylaşmak istemedikleri, öğrencilere ders esnasında söz hakkı tanındığı, zorunlu uzaktan eğitim sonrasında takviye eğitimler yapılabileceği, uzaktan eğitimde ölçme ve değerlendirmelerin gerçeği kısmen yansıttığını düşündükleri ve öğrencileri ödev yoluyla değerlendirmeye çalıştıkları belirlenmiş̧tir. Ortaya çıkan sonuçlara dayanarak uzaktan eğitim platformlarına yönelik öğretim elemanları ve öğrencilere eğitim verilmesi, alternatif ölçme değerlendirme tekniklerinden daha fazla faydalanılması gibi önerilerde bulunulmuştur.

Anahtar Kelimeler: Covid-19, öğretim elemanları, uzaktan eğitim.

\section{Evaluation of Distance Education in Terms of Academics: Covid-19 Pandemic}

\begin{abstract}
This study aimed to reveal the views of the faculty of education academics, who continued their lessons through distance education during the Covid-19 pandemic, regarding distance education. In this study, descriptive research design was preferred. The academics participated in the study were determined by convenience sampling, one of the non-random sampling methods. An online questionnaire prepared by the researchers was utilized to collect data from academics. Data was analyzed by descriptive statistics. According to the results; it was found that the majority of the academics have mastered the Adobe Connect program, the use of the Adobe Connect program in distance education is partially sufficient, the biggest obstacle in the implementation of distance education is the infrastructure inadequacies, the application of distance education is partially efficient for the student, and the majority of the teaching methods and techniques used in the lessons are verbal expressions. The duration of the distance education lessons is sufficient, the academics do not want to share the course contents because they think they may experience ethical violations with the students, students are given the right to speak during the lessons, supplementary education can be done after compulsory distance education, academics think that the measurement and evaluations in distance education partially reflect the reality and they preferred to evaluate the students by homework. Based on the results, suggestions such as providing
\end{abstract}


education to academics and students for distance education platforms, and making more use of alternative assessment and evaluation techniques were made.

Keywords: Covid-19, academics, distance education.

\section{Giriş}

Covid-19 pandemisi sebebiyle dünyada sağlık, ekonomi, eğitim gibi birçok alanda beklenmedik sonuçlar ortaya çıkmıştır. Bu nedenle toplumda, insan sağlı̆̆ının salgından olabildiğince az etkilenebilmesi için toplu yaşam alanlarına kısıtlamalar getirilmiştir. Eğitim alanını da içine alan bu kısıtlamalar sonucunda pek çok ülkede olduğu gibi ülkemizde de uzaktan eğitime geçilmiştir.

Uzaktan eğitim kavramının net bir şekilde anlaşılabilmesi için bu kavramın tanımının bilinmesi gerekmektedir. Türk Dil Kurumu (TDK, 2021) uzaktan eğitimi, öğrenen ile öğreticinin bir arada bulunmadığı, farklı eğitim ve öğretim araçları ile öğretimin gerçekleştirilmesi olarak tanımlamaktadır. Kaçan ve Gelen'e (2020) göre uzaktan eğitim, öğrenenin ve öğretenin, fiziksel olarak aynı ortamda bulunmadan, teknolojik araçlar sayesinde eğitimin senkron ve asenkron olarak sürdürülmesidir

Uzaktan eğitimin uygulanmasında sadece teknolojinin ve öğrenme ortamlarının birleştirilmesi tek başına yeterli değildir. Eğitim ve öğretimin tam anlamıyla yapılabilmesi için dersin işleneceği platformun da iyi olması gerekmektedir. Bunlara ek olarak uzaktan eğitim, öğrenmenin senkron ve asenkron ortamlarda sağlanmasına, katılımcılara yazılı, görsel, işitsel ve bilgilendirici etkinliklerin sunulmasına da olanak sağlamaktadır (Sayan, 2020). Uzaktan eğitim platformları bu özellikleri sayesinde geniş kitlelere ulaşmada daha etkili olmaktadır (Şen, 2016). Mevcut çalışmalarda da uzaktan eğitimin senkron ve asenkron olarak yapılabilmesinin avantajları mevcuttur. Örneğin; derslerin zaman ve mekândan bağımsız olması ve sonradan tekrar edilebilmesi avantaj olarak görülmektedir (Gregory ve Lodge, 2015; Özgöl, Sarıkaya ve Öztürk, 2017; Sadeghi, 2019). Ancak bu olumlu yönün aksine internette aksaklıklar yaşanması (Tuncer ve Bahadır, 2017), etkileşim eksikliği (Arkorful ve Abaidoo, 2015; Bayburtlu, 2020; Sadeghi, 2019), teknik aksaklıklar (Erol Şahin, 2019), derse katılımda çekingen davranma (Gürer, Tekinarslan ve Yavuzalp, 2016) gibi dezavantajları da mevcuttur.

Alanyazında uzaktan eğitim hakkında yer alan bu bilgiler araştırma yapılan içeriğe, zamana ve duruma bağlı olarak değişkenlik göstermektedir. Özellikle 2019 yılında Çin'de ortaya çıkan Covid-19 pandemisinin 16 Mart 2020 tarihinde ülkemize gelmesiyle beraber çoğu öğrenci, eğitim- öğretimlerine evlerinde devam etmektedir. Öğrencilerin ve eğitmenlerin eğitim ve öğretimlerine hazırlıksız bir şekilde evlerinde devam etmeleri sonucunda farklı problemler ortaya çıkmıştır. Örneğin Karadağ ve Yücel (2020) uzaktan eğitimi lisans öğrencileri bakış açısına göre değerlendirdikleri çalışmalarında, lisans öğrencilerinin \%63'ünün evinde internet olmadığını belirlemişlerdir. Ayrıca öğrencilerin derslere erişim sağlamada bilgisayar ve tabletlere sahip olan öğrenci sayısının yetersiz olduğu ve buna bağlı olarak öğrencilerin dörtte birinin derslere devam sağlayamadıkları tespit edilmiştir. Alanyazındaki diğer çalışmalar incelendiğinde Covid-19 pandemisi öncesinde; akademisyenlerin uzaktan eğitime karş1 inançları (Yıldız, 2015), hazırbulunuşlukları (Koloğlu, Kantar ve Doğan, 2016) ve görüşleri (Barış ve Çankaya, 2016; Erol Şahin, 2019; Gürer, Tekianarslan ve Yavuzalp, 2016) çalışmaları bulunmaktadır. Öğrenciler açısından ise; üniversite öğrencilerinin görüşleri (Pepeler, Özbek ve Adanır, 2018; Tuncer ve Bahadır, 2017), algıları (Cacheiro Gonzalez, Medina Rivilla, Dominguez Garrido ve Medina Dominguez, 2018), tutumları (Barış, 2015), öğrencilerin uzaktan eğitim hakkında kalite değerlendirmeleri (Gonu ve Agyepong, 2016) gibi çalışmalar bulunmaktadır. Covid-19 pandemi sürecinde ise; öğretmen adaylarının çevrimiçi eğitime nasıl baktıkları (Karatepe, Küçükgençay ve Peker, 2020), öğrenci görüşleri (Andoh, Appiah ve Agyei, 2020; Duban ve Şen, 2020; Sakarya ve Zahal, 2020), öğrenci deneyimleri (Kara, 2020; Karahan, Bozan ve Akçay, 2020), niyet ve tutumları (Çakır ve Arslan, 2020), akademisyenlerin görüşleri (Serçemeli ve Kurnaz, 2020), öğretmen görüşleri (Bayburtlu, 2020), uzaktan eğitimin etkililiği (Başaran, Doğan, Karaoğlu ve Şahin, 2020), ülkelerin pandemi sürecinde nasıl bir eğitim politikası izlediği (Telli Yamamoto ve Altun, 2020), uzaktan eğitim sürecinde öğrencilerin ölçme ve değerlendirme deneyimlerinin belirlenmesi (Aksu Dünya, Şahin ve Aybek, 2021), öğrencilerin uzaktan eğitimden beklentileri, tatminkârlıkları ve performansları açısından değerlendirilmesi (Özgen ve Reyhan, 2020) ile ilgili çalışmalar yapılmıştır. 
Uzaktan eğitim üzerine yapılan çalışmalar pandemi öncesi ve pandemi esnası olarak değerlendirildiğinde; araştırılan konuların öğrenci, öğretmen ve akademisyenlerin uzaktan eğitime yönelik tutum, alg1, inanç ve görüşleri gibi genel bir çerçevede olduğu dikkat çekmektedir. İçinde bulunduğumuz pandemi sürecinin normale ne zaman döneceğinin net olarak bilinmemesi ve eğitimlerin uzaktan gerçekleştirilmesi hem öğrencileri hem de eğitimcileri etkilediği açıktır. Bu nedenle, pandemi döneminde mecburi olarak uzaktan yürütülen eğitimlerin mevcut durumdan daha iyi duruma gelmesi gerektiği düşünülmektedir. Buna yönelik olarak öğretmen yetiştiren akademisyenlerin uzaktan eğitim hakkındaki düşünceleri önem arz etmektedir. Bu çalışmada diğer çalışmalardan farklı olarak eğitim fakültesinde görev yapan öğretim elemanlarının Covid-19 pandemi sürecinde uzaktan eğitimi nasıl değerlendirdiklerinin belirlenmesi amaçlanmıştır. Amaca yönelik olarak bu çalışmada öğretim elemanlarının uzaktan eğitimde ne tür aksaklıklar yaşadıkları, uzaktan eğitim programına uyum sağlayabilme durumları, derslerini nasıl yürüttükleri, derslerini işlerken destekleyici yöntem ve teknikler kullanma durumları, uzaktan eğitimde öğrencilerle ders esnasında iletişimleri ve sınavlarını ne şekilde uygulamayı tercih ettikleri gibi durumlar incelenmiştir. Uzaktan eğitimin, eğitim fakültesinde görev yapan ögretim elemanlarına göre değerlendirilmesi uzaktan eğitim çalışmalarına yeni bir boyut katacağı ve mevcut durumun belirlenmesinin yapılacak yeni çalışmalara fikir vermesi açısından önemlidir.

\section{Yöntem}

\section{Araştırmanın Yöntemi}

Çalışmada betimsel araştırma yöntemi tercih edilmiştir. Betimsel araştırma, kişinin/kişilerin davranışları, fikirleri ve mevcut durumların değerlendirilmesi amacıyla var olan durumun betimlenmesidir (Büyüköztürk, Kılıç Çakmak, Akgün, Karadeniz ve Demirel, 2019, s. 24). Çalışmada eğitim fakültesinde görev yapan öğretim elemanlarının uzaktan eğitim sürecine yönelik mevcut durumu değerlendirmeleri amacıyla betimsel araştırma yöntemi kullanılmıştır.

\section{Çalışma Grubu}

Çalışma, pandemi sürecinde bir eğitim fakültesinde derslere giren 20'si erkek 15'i kadın olmak üzere toplam 35 gönüllü öğretim elemanı ile gerçekleştirilmiştir. Çalışma grubu belirlenirken seçkisiz olmayan örnekleme yöntemlerinden uygun örnekleme yöntemi tercih edilmiştir. Uygun örnekleme yöntemi, zaman, para ve iş gücü kaybı açısından ekonomik çalışmalar yapılmasına olanak vermektedir (Büyüköztürk vd., 2019, s. 95). Bu çalışmada da öğretim elemanlarına pandemi sürecinde daha hızlı ulaşılabilmesi, zaman ve maliyet açısından ekonomik olması nedeniyle uygun örnekleme tercih edilmiştir.

\section{Veri Toplama Araçları}

Çalışmada veriler, araştırmacılar tarafından hazırlanan Google Formlar üzerinden uygulanan 18 soruluk anket aracılı̆̆ıyla toplanmışır. Anketin hazırlanma aşamasında ilk olarak ilgili alanyazın incelenmiştir. Alanyazın incelenirken öğretim elemanlarının mevcut duruma bakış açılarının geniş bir açıdan incelenebilmesi için "Örgün eğitimde nelere dikkat ediyoruz?" ve "Örgün eğitimde dikkat ettiğimiz durumlar uzaktan eğitimde nasıl değişti?" şeklinde karşılaştırmalar yapılarak anketin oluşturulabilmesi için anahtar kelimeler oluşturulmuştur. Bahsedilen anahtar kelimeler 'uzaktan eğitim' 'Adobe Connect', 'uzaktan eğitimde uygulamalar', 'uzaktan eğitimde sınıf yönetimi' ve 'uzaktan eğitimde ölçme ve değerlendirme' şeklindedir. Bu anahtar kelimelere uygun olarak anket soruları hazırlandıktan sonra sorular genelden özele doğru olacak şekilde sıralanmıştır. Hazırlanan taslak formun uygunluğun kontrol edilebilmesi amacıyla iki uzmanın (Türkçe eğitimcisi bir uzman ve uzaktan eğitim alanında çalışmaları olan bir uzman) görüşleri alınmıştır. Uzmanlardan gelen geri dönütler neticesinde 'Öğretimi aşağıdakilerden hangilerini kullanarak gerçekleştiriyorsunuz? (Birden çok şık seçebilirsiniz)' şeklinde birden fazla şıkkın işaretlenebileceği üç soru 'Uzaktan eğitimin etkili olduğunu düşünüyor musunuz?' şeklinde hazırlanan ve cevapları 'Evet', 'Hayır' ve 'Kısmen' şeklinde olan 15 kısa soru 
cümlesi arasına yerleştirilmiştir. Oluşturulan anketin ön uygulamasının yapılması için çalışmaya dahil edilmeyen eğitim fakültesinde görev yapan öğretim elemanlarına uygulanmıştır. Yapılan ön uygulamanın verileri analiz edilerek düzeltilmesi gereken yerler düzeltilmiştir. Son kontrollerden sonra ankete son hali verilmiştir.

\section{Verilerin Toplanması ve Analizi}

Bu çalışmada, öğretim elemanlarından anket aracılığıyla toplanan verilerin analizinde betimsel istatistik yöntemleri tercih edilmiştir. Betimsel istatistik yöntemleri, çalışılan durumun bulgularının ortaya konulmasında frekans, yüzde, merkezi eğilim ölçüleri gibi tekniklerle gösterilmesidir (Büyüköztürk, 2020, s. 5). Yapılan çalışmada yüzde ve frekanslar kullanılarak bulgular yorumlanmıştır.

\section{Araştırma Etiği}

Yapılan çalışmada "Yükseköğretim Kurumları Bilimsel Araştırma ve Yayın Etiği Yönergesi”" kapsamında bütün kurallara uyulmuştur. Buna ek olarak yapılan çalışma için Süleyman Demirel Üniversitesi Sosyal ve Beşeri Bilimler Araştırma ve Yayın Etiği Kurulunun 28.12.2020 tarih ve 100/07 sayılı etik kurul onayı alınmıştır.

\section{Bulgular}

Yapılan çalışmadan elde edilen bulgular "Adobe Connect programının kullanılmasına ilişkin öğretim elemanı değerlendirmeleri”, "uzaktan eğitimin uygulanmasına ilişkin öğretim elemanlarının değerlendirmeleri", "uzaktan eğitim esnasında sınıf yönetimine ilişkin öğretim elemanlarının değerlendirmeleri", "uzaktan eğitim sınav sistemine ilişkin öğretim elemanları değerlendirmeleri” ve "uzaktan eğitim sonrasına ilişkin öğretim elemanları değerlendirmeleri" kategorilerinde sunulmuştur.

\section{Adobe Connect Programının Kullanılmasına İlişkin Öğretim Elemanı Değerlendirmeleri}

Bu kategoride öğretim elemanlarının Adobe Connect programına hâkim olma durumları ve programın uzaktan eğitimde yeterli bulma durumları Şekil 1 ve Şekil 2 ile ortaya konulmuştur.

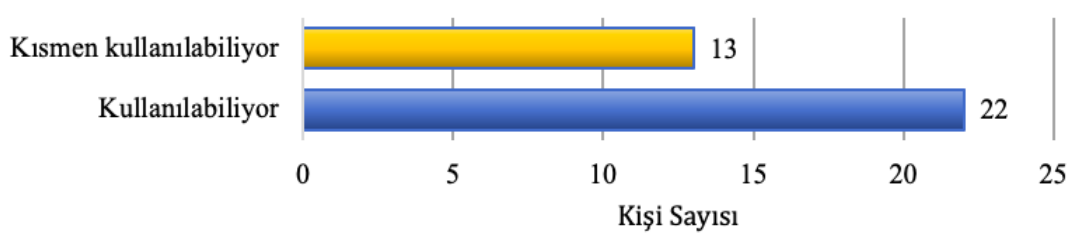

Şekil 1. Adobe Connect Programının Kullanabilme Durumu

Şekil 1'de verilen öğretim elemanlarının Adobe Connect programına hâkim olma durumları dikkate alındığında 22 öğretim elemanı Adobe Connect programına hâkim olduğunu belirtirken, 13 öğretim elemanı programa kısmen hâkim olduğunu belirtmiştir. Programa hâkim olmadığını belirten ögretim elemanı ise yoktur.

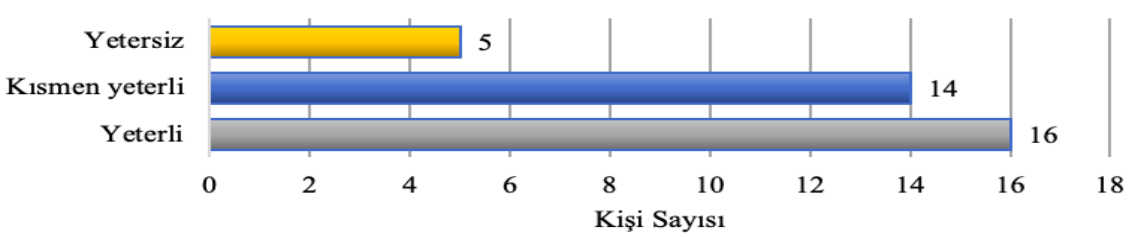

Şekil 2. Uzaktan Eğitimde Adobe Connect Programının Yeterli Bulunma Durumu 
Şekil 2'de öğretim elemanlarının uzaktan eğitimde Adobe Connect programının kullanılmasına yönelik değerlendirmeleri yer almaktadır. Şekil 2’ye göre 16 öğretim elemanının Adobe Connect programının uzaktan eğitim için yeterli olduğunu, 14 öğretim elemanının programın kısmen yeterli olduğunu ve 5 öğretim elemanının ise yeterli olmadığını belirttiği görülmektedir.

\section{Uzaktan Eğitim Derslerinin Uygulanmasına İlişkin Öğretim Elemanı Değerlendirmeleri}

$\mathrm{Bu}$ kategoride Covid-19 pandemi sürecinde uzaktan eğitimin yapılmasına ilişkin öğretim elemanları açısından eğitimi uygulamadaki problemler, eğitimin etkililiği ve verimliliği, ders esnasında kullanılan yöntem ve teknikler, ders sürelerinin yeterliliği, öğretim elemanlarının doküman sunabilme durumları ve öğretim elemanlarının öğrencilerle etik sorun yaşama durumları ele alınmıştır.

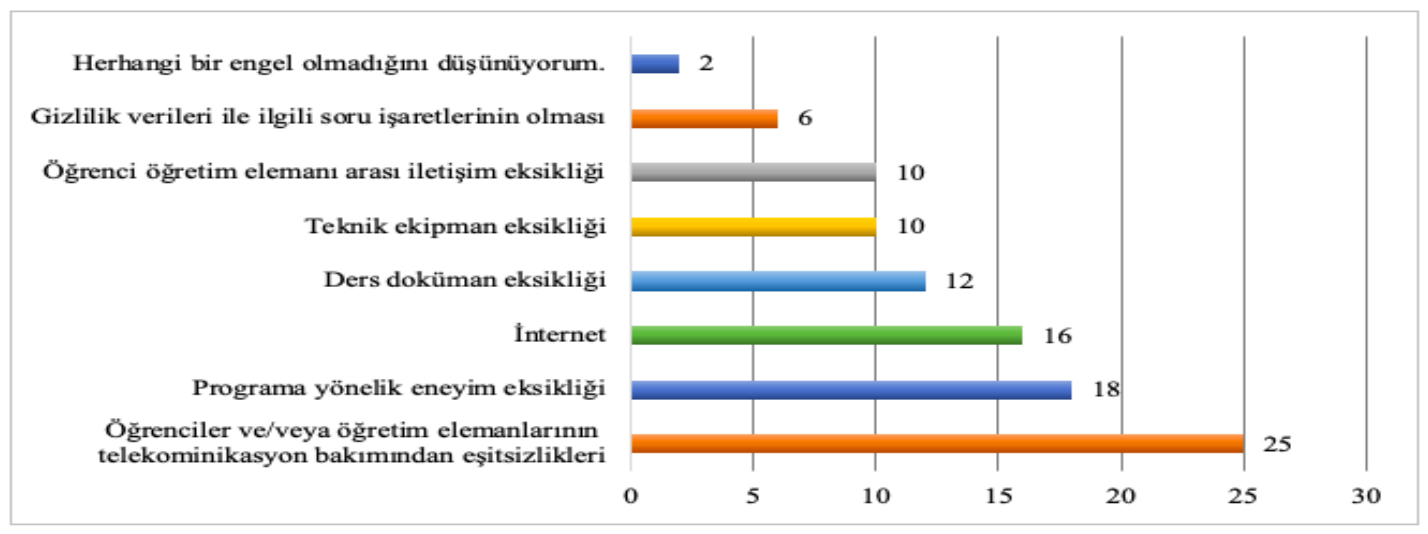

Şekil 3. Uzaktan Eğitim İlkelerinin Uygulanamaması Önündeki Engeller

Uzaktan eğitim ilkelerinin tam olarak uygulanamamasının önündeki başlıca engellerin öğretim elemanlarına göre değerlendirilmesi incelenmiştir (Şekil 3). Buna göre öğrenciler ve/veya öğretim elemanlarının telekomünikasyon bakımından eşitsizlikler (25), programa yönelik deneyim eksiklikleri (18), internet yetersizliği (16), ders dokümanı eksikliği (12), teknik ekipman eksikliği (10), öğrenciöğretim elemanı arasında iletişim eksikliği (10) ve gizlilik verileri ile ilgili soru işaretlerine (6) bağlı olarak uzaktan eğitim ilkelerinin tam olarak uygulanamadığını belirtirken 2 öğretim elemanı herhangi bir engelin olmadığını belirtmiştir.

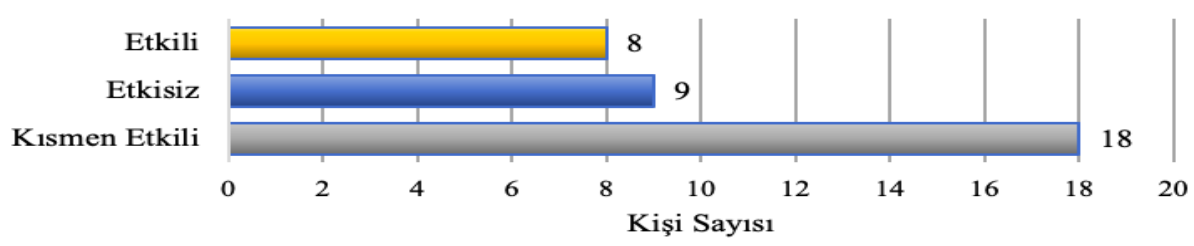

Şekil 4. Uzaktan Eğitimin Etkililiğine İlişkin Görüşleri

Öğretim elemanlarının uzaktan eğitimin verimliliğine ilişkin değerlendirmesi incelendiğinde; 18 öğretim elemanının uzaktan eğitimin kısmen etkili olduğunu, 9 öğretim elemanı etkili olmadığını ve 8 öğretim elemanı ise etkili olduğunu belirtmiştir (Şekil 4).

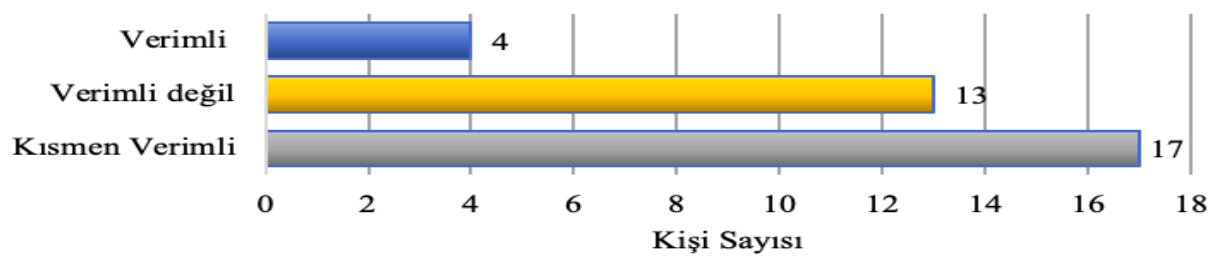

Şekil 5. Uzaktan Eğitimin Verimliliğine İlişkin Görüşler 
Öğretim elemanlarının uzaktan eğitimin verimliliğine ilişkin değerlendirmelerinde; 17 öğretim elemanı uzaktan eğitimden kısmen verim alabildiğini, 13 öğretim elemanı verim alamadığını ve 4 öğretim elemanı ise uzaktan eğitimden verim aldığını belirtmiştir. Bir öğretim elemanı ise herhangi bir cevap vermemiştir (Şekil 5).

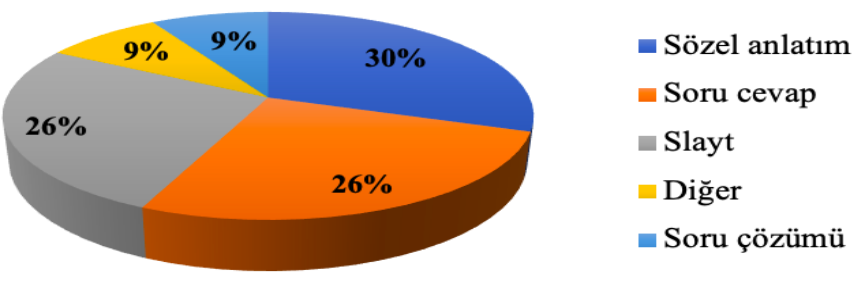

Şekil 6. Uzaktan Eğitim Esnasında Kullanılan Öğretim Yöntem ve Teknikler

Şekil 6'da öğretim elemanlarının uzaktan eğitim dersleri sırasında kullandıkları öğretim yöntem ve tekniklerin dağılımı incelenmiş ve öğretim elemanlarının \%30'u (32 öğretim elemanı) uzaktan eğitimde sözel anlatım, \%26's1 (28 öğretim elemanı) slayt, \%26's1 (28 öğretim elemanı) soru-cevap, \%9'u (9 öğretim elemanı) soru çözümü, \%9'u (9 öğretim elemanı) ise belirtilen yöntemler dışında farklı yöntemler de kullandıklarını belirlenmiştir.

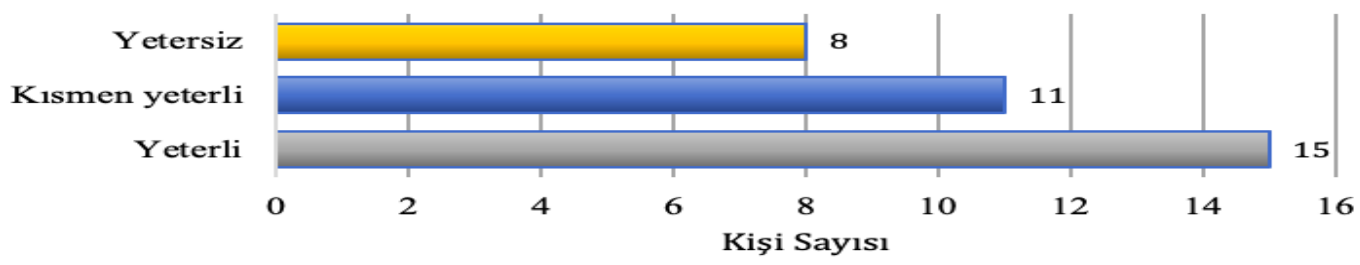

Şekil 7.Uzaktan Eğitim Ders Süreleri Hakkında Görüşler

Öğretim elemanlarının uzaktan eğitim ders sürelerine ilişkin görüşleri değerlendirildiğinde; 15 öğretim elemanı uzaktan eğitim sürecinde ders işlemek için verilen süreleri yeterli bulduğunu, 11 öğretim elemanının ise kısmen yeterli bulduğunu ve 8 öğretim elemanı ise sürenin yetersiz olması sebebiyle bu sürenin üzerinde ders işlemek zorunda kaldığını belirtmiştir. Bir öğretim elemanı ise herhangi bir cevap vermemiştir (Şekil 7).

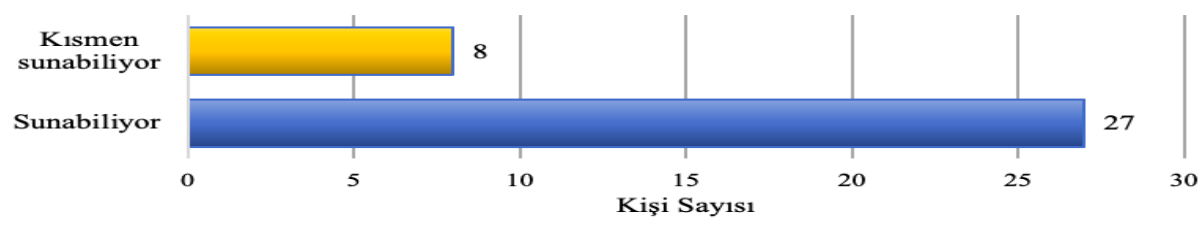

Şekil 8. Uzaktan Eğitim Derslerinde Doküman Sunabilme Durumu

Öğretim elemanlarının uzaktan eğitim sürecinde öğrencilerine doküman sunabilme durumlarına ilişkin görüşleri incelendiğinde; 27 öğretim elemanı öğrencilerine destekleyici ders dokümanları sunabildiğini ve 8 öğretim elemanı ise kısmen doküman sağlayabildiğini belirtmiştir (Şekil 8). 


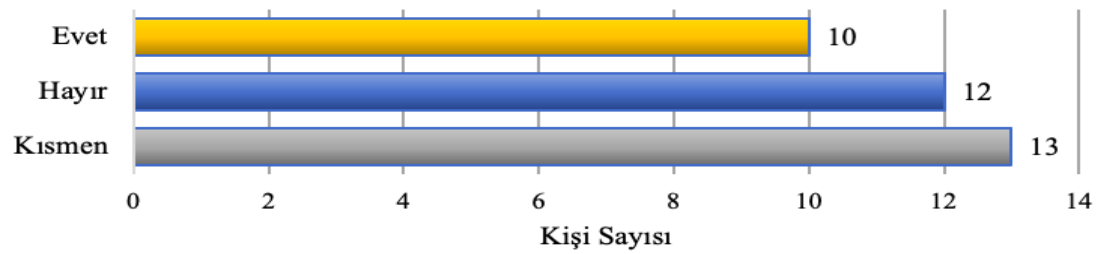

Şekil 9. Uzaktan Eğitim Derslerinde Dokümanların Paylaşımında Etik Sorunlar Yaşamalarına İlişkin Durumlar

Öğretim elemanlarının ders dokümanlarını öğrencileriyle paylaşmalarında etik sorunlar yaşamalarına ilişkin görüşleri incelendiğinde; 13 öğretim elemanının kısmen bir etik sorun olabileceğini, 12 öğretim elemanının etik bir sorun olacağını ve 10 öğretim elemanının ise etik yönden sorunlar olabileceğini düşündüğünü belirtmişlerdir (Şekil 9).

\section{Uzaktan Eğitim Esnasında Sınıf Yönetimine İlişkin Öğretim Elemanları Değerlendirmeleri}

Bu kategoride uzaktan eğitim sürecinde çevrimiçi olarak ders yapan öğretim elemanlarının sınıf yönetimlerine ilişkin değerlendirmeleri ele alınmıştır.

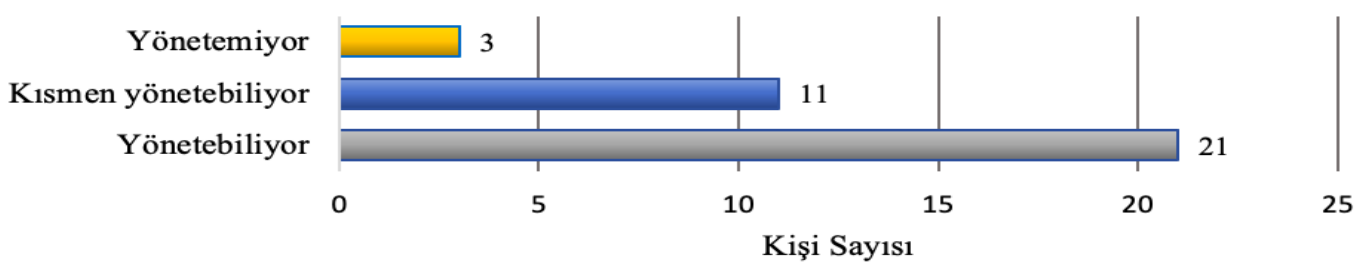

Şekil 10. Uzaktan Eğitimde Sınıf Yönetimine İlişkin Görüşler

Şekil 10'da öğretim elemanlarının uzaktan eğitim derslerinde sınıf yönetimlerine yönelik değerlendirmeleri yer almaktadır. Şekil 10'a göre 21 öğretim elemanı sınıf yönetiminde problem yaşamadığını, 11 öğretim elemanı kısmen bir sınıf yönetim problemi yaşadığını ve 3 öğretim elemanı ise ders boyunca bir sınıf yönetimi problemi yaşamadığını belirttiği görülmektedir.

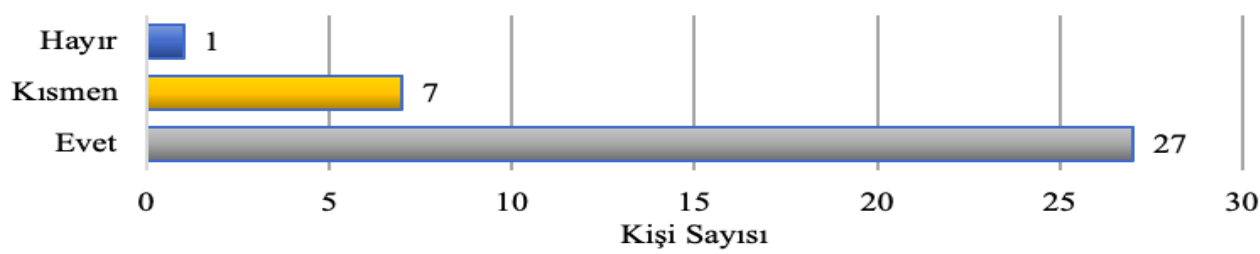

Şekil 11. Uzaktan Eğitim Dersleri Esnasında Öğrencilerine Söz Hakkı Vermelerine İlişkin Görüşler

Şekil 11'de göre uzaktan eğitim derslerinde öğretim elemanlarının öğrencilerine söz hakk1 verme durumları yer almaktadır. Şekil 11'e göre 27 öğretim elemanının ders esnasında öğrencilere söz hakkı verdiğini, 7 öğretim elemanının kısmen söz hakkı verdiğini ve 1 öğretim elemanının ise öğrencilere ders esnasında söz hakkı vermediği anlaşılmaktadır.

\section{Uzaktan Eğitimde Ölçme ve Değerlendirmeye İlişkin Öğretim Elemanları Değerlendirmeleri}

Bu kategoride uzaktan eğitim derslerinin çevrimiçi olarak ölçme ve değerlendirme yapılmasına ilişkin öğretim elamanı değerlendirmeleri ele alınmıştır. 


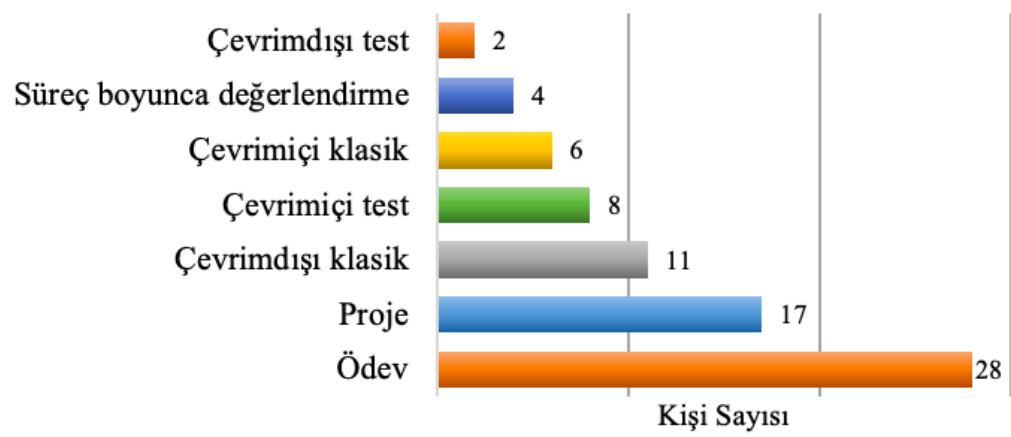

\section{Şekil 12. Uzaktan Eğitimde Öğrencilerin Değerlendirilme Yöntemleri}

Şekil 12'de öğretim elemanlarının uzaktan eğitim sürecinde öğrencilerini sınav süreçlerinde ne şekillerde değerlendirdikleri görülmektedir. Şekil 12'ye göre vize, final ve bütünleme sınavlarında 28 öğretim elemanının ödev, 17 öğretim elemanın proje, 11 öğretim elemanın çevrim dışı klasik sınav, 9 öğretim elemanın çevrim içi test, 6 öğretim elemanın çevrimiçi klasik, 2 öğretim elemanın çevrim dışı testi tercih ettiğini belirtirken 4 öğretim elemanı ise bu süreç boyunca öğrencilerin değerlendirilmemesi gerektiğini belirtmiştir.

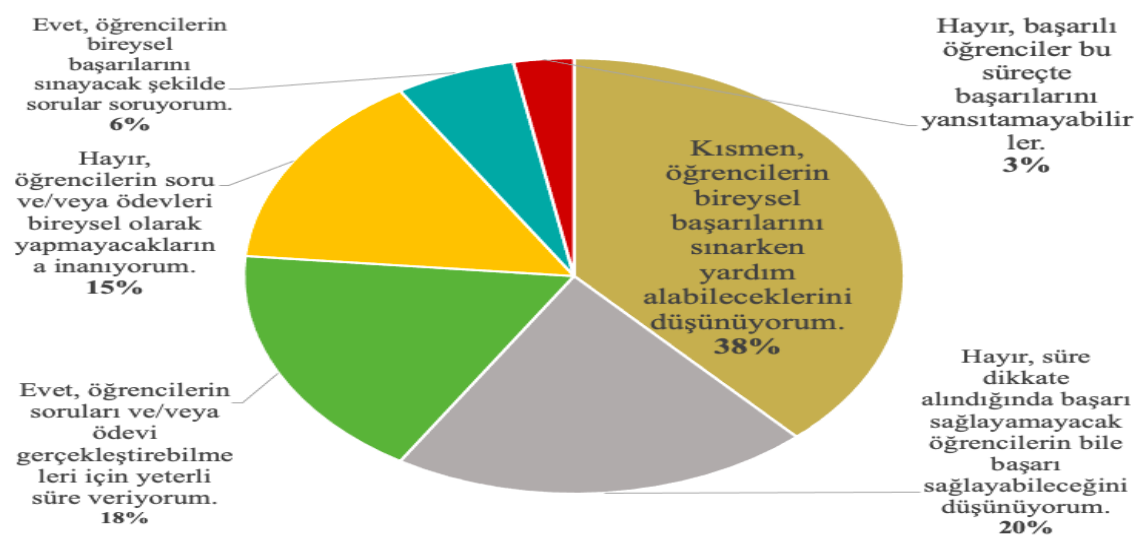

Şekil 13. Uzaktan Eğitimde Yapılan Değerlendirmelerin Gerçeği Yansıtıp Yansıtmama Durumu

Şekil 13'te uzaktan eğitim sonunda gerçekleştirilen vize, final ve bütünleme sınavlarının gerçeği yansıtma durumuna göre öğretim elemanları değerlendirmeleri yer almaktadır. Şekil 13'e göre 13 öğretim elemanı kısmen, öğrencilerin bireysel başarılarını sınarken yardım alabileceklerini düşünüyorum; 7 öğretim elemanı hayır, süre dikkate alındığında başarı sağlayamayacak öğrencilerin bile başarı sağlayabileceğini düşünüyorum; 6 öğretim elemanı evet, öğrencilerin bireysel başarılarını sınayacak şekilde süre veriyorum; 5 öğretim elemanı hayır, öğrencilerin soru ve/veya ödevleri bireysel olarak yapmayacaklarına inanıyorum; 2 öğretim elemanı evet, öğrencilerin bireysel başarılarını sınayacak şekilde sorular soruyorum; 1 öğretim elemanı hayır, başarılı öğrenciler bu süreçte başarılarını yansıtamayabilirler cevabını verdiği görülmektedir. Bir öğretim elemanı ise herhangi bir cevap vermemiştir.

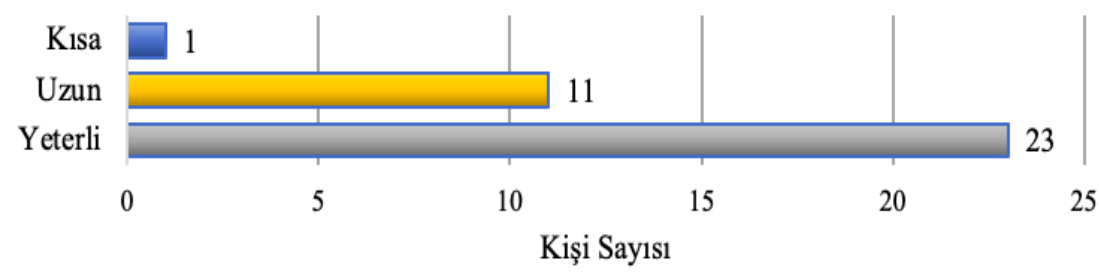

Şekil 14. Uzaktan Eğitim Sınav Sürelerine İliş̧kin Görüşler 
Öğretim elemanlarının uzaktan eğitim sürecinde sınav sürelerini nasıl buldukları incelendiğinde; 23 ögretim elemanı bu süreçte gerçekleştirilen vize, final ve bütünleme sınavlarının sürelerinin yeterli olduğunu, 11 öğretim elemanı gerekenden çok daha uzun olduğunu ve 1 öğretim elemanı verilen sürenin sınavlar için kısa olduğunu belirtmiştir (Şekil 14).

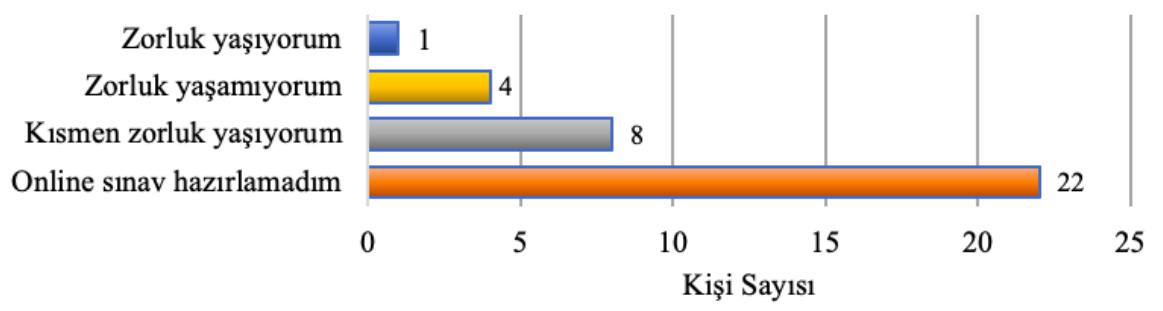

Şekil 15. Çevrimiçi Sınav Hazırlamaya İlişkin Görüşler

Şekil 15'te öğretim elemanlarının çevrimiçi sınav hazırlamada zorluk yaşama durumları yer almaktadır. Şekil 15'e göre 1 öğretim elemanı zorluk yaşadığını, 8 öğretim elemanı kısmen zorluk yaşadığını ve 4 öğretim elemanı ise zorluk yaşamadığını belirtirken, 22 öğretim elemanı ise bu süreç içerisinde çevrimiçi sınav hazırlamadığını belirtmiştir.

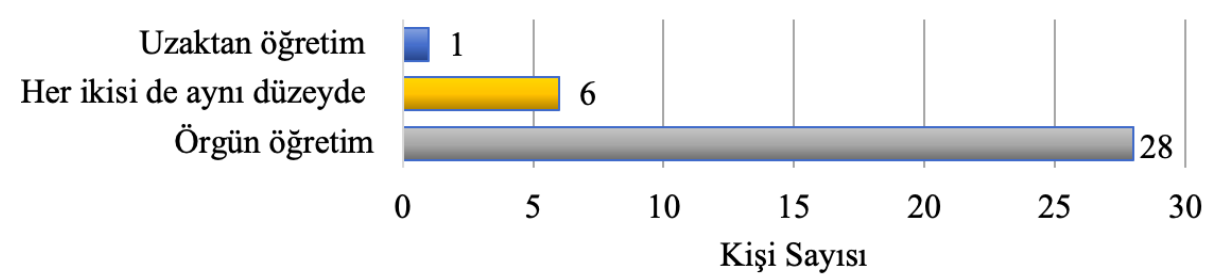

Şekil 16. Öğrencilerin Öğrenme Düzeylerini Belirlemede Uzaktan Eğitim ve Örgün Eğitime İlişkin Görüşler

Öğretim elemanları öğrenme düzeylerinin belirlenmesinde çevrimiçi öğretim ile örgün öğretim sürecini kıyasladığında 28 öğretim elemanı örgün eğitimde öğrenme düzeylerinin belirlenmesinin daha kolay olduğunu, 6 öğretim elemanı her ikisi arasında bir farklılık olmadığını ve 1 öğretim elemanı ise çevrimiçi eğitimde öğrenme düzeylerinin belirlenmesinin daha kolay olduğunu belirtmiştir (Şekil 16).

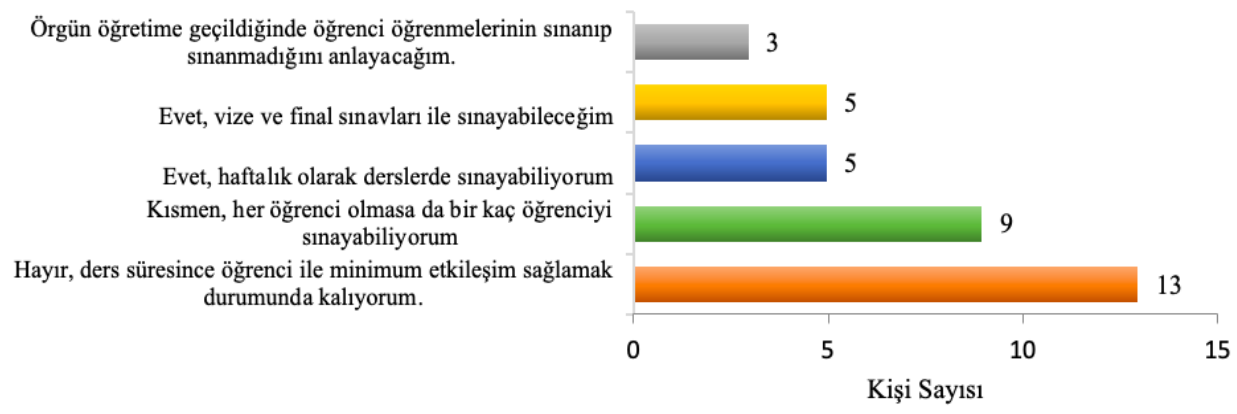

Şekil 17. Öğrencilerin Sınanmalarına İlişkin Değerlendirmeler

Şekil 17'de öğretim elemanlarının uzaktan eğitim sürecinde öğrencilerini sınama durumlarına ilişkin görüşleri yer almaktadır. Şekil 17'ye göre 13 öğretim elemanı uzaktan eğitim sürecinde öğrencilerin öğrenmelerini sınayamadığını ve ders süresince öğrenci ile minimum etkileşim sağlamak durumunda kaldığını, 9 öğretim elemanı her öğrenci olmasa da birkaç öğrenciyi sınayabildiğini, 5 öğretim elemanı vize ve final sınavları ile sınayabileceğini ve 5 öğretim elemanı haftalık olarak derslerde 
sınayabildiğini belirtirken, 3 öğretim elemanı ise uzaktan eğitim sürecinde öğrenci öğrenmelerinin sınayıp sınayamadığını örgün öğretime geçtiklerinde anlayabileceklerini belirtmiştir.

\section{Uzaktan Eğitim Sonrasına İlişkin Öğretim Elemanları Değerlendirmeleri}

Bu kategoride uzaktan eğitim derslerinin çevrimiçi olarak ölçme ve değerlendirme yapılmasına ilişkin öğretim elamanı değerlendirmeleri ele alınmıştır.

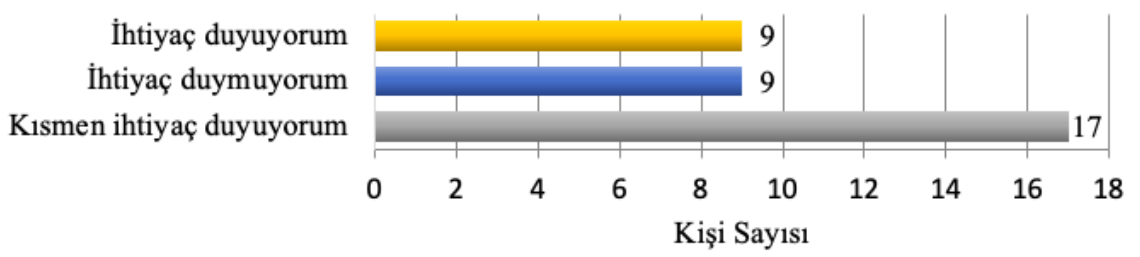

Şekil 18. Pandemi Sonrası Takviye Yapılmasına İlişkin Değerlendirmeler

Şekil 18'de zorunlu uzaktan eğitim süreci sonunda öğrencilere takviye derslerin yapılmasına yönelik öğretim elemanları görüşleri yer almaktadır. Şekil 18'e göre 17 öğretim elemanı bu süreç sonrasında takviye örgün öğretim derslerine kısmen ihtiyaç olduğunu, 9 öğretim elemanı ihtiyaç olmadığını ve 9 öğretim elemanı ise ihtiyaç olduğunu belirtmiştir.

\section{Sonuç, Tartışma ve Öneriler}

Öğretim elemanlarının yaklaşık \%63'ünün Adobe Connect programına hâkim olduğu Şekil 1'den anlaşılmaktadır. Programa hâkim olmadığını belirten öğretim elemanı ise hiç yoktur. Bu durum eğitim fakültesinde görev yapan ve programa hâkim olan öğretim elemanlarının bu veya benzeri uzaktan eğitim programlarını daha önce kullandıklarını; kısmen hâkim olanların ise daha önce uzaktan eğitim ortamlarında eğitim faaliyetlerine katılmamış olabileceklerini, programı öğrenmedeki hızları ve bilgiteknoloji becerilerine tam olarak hâkim olmamalarından kaynaklanabileceği düşünülmektedir. Uzaktan eğitim uygulamaları günümüzde teknolojik cihazlarla yapılmaktadır. Bu cihazlar herkes tarafindan başarılı bir şekilde kullanılamayabilinir. Örneğin Yıldız (2020) çalışmasında özellikle yaşlı akademisyenlerin teknolojik altyapıyı kullanmayı çok başaramadıkları yönünde bir sonuca ulaşmıştır. Ayrıca gerek öğretim elemanlarının gerek öğretmenlerin benzer programları kullanmada yeterli olmadıklarına dair diğer çalışmalarda da ortaya konulmuştur (Bakioğlu ve Çevik, 2020; Karadağ ve Yücel, 2020; Üstün, 2011).

Covid 19 pandemi sürecinde eğitim öğretim faaliyetleri üniversitelerin tercih ettikleri bir uzaktan eğitim altyapısı ile sürdürülmüştür. Bu çalışmada bir devlet üniversitesinin tercih ettiği Adobe Connect programı öğretim elemanları görüşlerine göre değerlendirilmiştir. Ortaya çıkan sonuçlara göre öğretim elemanlarının çoğu uzaktan eğitim sürecinde Adobe Connect programının kullanılmasını yeterli bulmaktadır. Buna karşın programın kısmen yeterli olduğu görüşünde olan öğretim elemanlarının sayısı da oldukça fazladır. Kısmen yeterli görüşünde olan öğretim elemanlarının programın yeterliliği konusunda net bir fikre sahip değiller şeklinde yorumlanmaktadır. Bunun nedeni olarak ise öğretim elemanlarının derslerini nasıl işledikleri, derslerinde öğrencileri gerek iletişim gerekse uygulama yapmak istemeleri etkili olabileceği düşünülmektedir.

Covid-19 pandemi sürecinde uzaktan eğitimin uygulanamaması önündeki engeller incelendiğinde öğretim elemanlarının en fazla telekomünikasyon bakımından eşitsizlikler, programa yönelik deneyim eksikliği, internet problemleri ve gizlilik verilerinin korunmasındaki şüphelerinin olması sebeplerinin bulunduğu tespit edilmiştir (Şekil 3). Bu durum uzaktan eğitimde teknik ve donanımsal eksiklerinin olduğunu göstermektedir. Ortaya çıkan bu sonuç Covid-19 pandemisi öncesi ve esnasında yapılan uzaktan eğitim çalışmaları ile örtüşür niteliktedir (Akkuş ve Acar, 2017; Bilgiç ve Tüzün, 2015; Can ve Köroğlu, 2020; Karadağ ve Yücel, 2020; Kırmac1 ve Acar, 2018; Sümer, 2016; Şenkal ve Dinçer, 2012; Tuncer ve Bahadır, 2017; Türker ve Dündar, 2020; Yıldız, 2020). 
Uzaktan eğitimin kısmen verimli ve kısmen etkili olduğu düşünülmektedir. Ortaya çıkan bu sonuç iki boyutta değerlendirilebilir. Birincisi öğretim elemanlarının ve öğrencilerin yarısı uzaktan eğitimi önemsemektedir ve kısmen de olsa verim alabilmektedir. Bu durum uzaktan eğitimin iyi bir tasarım ve uygulama sonucunda başarılı sonuçları ortaya çıkarabileceği fikri ile bağdaşmaktadır (Özonur, Kamışlı, Yanpar Yelken ve Sancar Tokmak, 2019). İkincisi ise öğretim elemanlarının diğer yarısı uzaktan eğitimin tam anlamıyla etkili ve verimli olmadığını düşünmektedir. Pandemi sürecinde eğitim öğretime dahil olan çoğu kişi uzaktan eğitime aniden başlamıştır. Pandeminin insanlar üzerinde bir tedirginlik yaşatması derslerin verimi ve etkililiği üzerinde payı vardır. Nitekim pandemi sürecinde yapılan benzer çalışmalarda da öğretim elemanlarının uzaktan eğitimin etkililiğinden ve verimliliğinden şüphe duydukları ve yüz yüze eğitimin daha verimli olduğunu düşündükleri de bilinmektedir (Balaman ve Hanbay Tiryaki, 2021; Patricia, 2020). Ayrica bu sonucun nedeni olarak Tuncer ve Tanaş (2011)'in de tespit ettikleri üzere uzaktan eğitim derslerinde etkileşim sınırlı̆̆ı ve öğrenmeye karşı bireysel yaklaşımların eğitimin verimini ve etkililiği üzerindeki etkisinden kaynaklanabilir. Buradan hareketle bu çalışmada öğretim elemanlarının uzaktan eğitim sürecinde öğrencilerinden bekledikleri sonuçları alamadıkları çıkarılabilir.

Uzaktan eğitim günümüzde sıklıkla internet gibi çevrimiçi ortamlarda gerçekleştirilmektedir. Gerek teknik gerek donanımsal gerekse bireyden kaynaklanan aksaklıklar sonucunda ders sürelerinde değişiklikler yaşanabilir. Bu çalışmada öğretim elemanlarının yaklaşık yarısının uzaktan eğitim süresini yeterli buldukları belirlenmiştir. Ortaya çıkan bu sonuç alanyazındaki diğer bir çalışma ile paralellik göstermemektedir. Örneğin Bakioğlu ve Çevik (2020) Covid-19 pandemi sürecinde fen bilimleri öğretmenlerinin uzaktan eğitime yönelik görüşlerini inceledikleri çalışmalarında öğretmenlerin derslerini yetiştirmede süre sıkıntısı çektiklerini belirlemişlerdir.

Öğretim elemanları uzaktan eğitim sürecinde derslerinde en fazla sözel anlatım ve soru cevap tekniğini tercih etmektedirler. Bunu soru çözümü ve diğer öğretim yöntem ve teknikleri takip etmektedir. Öğrencilerin derslerde aktif olmaları derse olan ilgilerini artırabilir. Nitekim yapılan bir çalışmada derste senkron olarak beyin furtınası ve tartışma tekniğinin uygulanabilmesinin uzaktan eğitimde uygun olduğu belirtilmiştir (Erfidan, 2019). Eroğlu ve Kalayc1 (2020), yabancı dil öğretimini uzaktan ve yüz yüze eğitim uygulamalarını karşılaştırarak değerlendirmişlerdir. Çalışmanın sonunda çeşitli bölümlerde öğrenim gören öğrencilerin, uzaktan eğitim sisteminde öğretim elemanlarının pasif olarak ders anlatmalarından hoşlanmadıkları tespit edilmiştir. Duman (2020), Covid 19 pandemi sürecinde uzaktan eğitim derslerinde genellikle soru cevap tekniğinin tercih edildiğini bu şekilde bir uygulamanın öğretim elemanı ve öğrencileri olumsuz olarak etkilediği belirlemiştir. Ayrıca öğretim elemanlarının derslerinde kullandıkları öğretim yöntem ve teknikleri alanyazındaki bir diğer çalışmayla daha benzerlik göstermektedir (Bakioğlu ve Çevik, 2020).

Öğretim elemanları derslerinde doküman sunabilmektedirler. Fakat kısmen doküman sunan öğretim elemanlarının sayısı da azımsanmayacak derecededir. Uzaktan eğitim derslerinin niteliği ders kaynakları ve materyallerin niteliğine göre değişebilmektedir (Chao, Saj ve Tessier, 2006). Ders esnasında materyallerin çeşitlendirilmemesi öğrencide olumsuz etki yaratabilmektedir. Bu da iyi bir öğrenmenin sağlanabilmesi için derste konuya uygun ve nitelikli kaynaklar kullanılması gerektiğini ortaya çıkarmaktadır (Başaran, Doğan, Karaoğlu ve Şahin, 2020; Ömeroğlu, 2019). Örneğin sözlü sunumlar, ders notları dijital yazım ve çizim araçları uzaktan eğitim sürecinde kullanılabilen dokümanlardan birkaçıdır (Karatepe, Küçükgençay ve Peker, 2020).

Öğretim elemanları öğrencilerle ders dokümanlarının paylaşımı konusunda etik sorunlar yaşanabileceğini düşünmektedirler. Özden, Özdemir Özden ve Biçer (2015) sinıf öğretmenliği öğrencileri ile gerçekleştirdikleri çalışmalarında; ders içeriğinin yoğun olması, yüksek not alma isteği, konuyu anlayamama gibi sebeplerden dolayı öğrencilerin akademik ihlal yaptıklarını belirlemişlerdir. Ayrıca yapılan çalışmanın bir diğer sonucu olarak öğretmen adaylarının en fazla gerçekleştirdikleri akademik usulsüzlükleri sınavdan sonra öğrencilerin sınav olmayan arkadaşları sınav içeriğinin paylaşılması ve sınav olmayan öğrencilerin öğrendikleri bilgilerle sınava girmiş olmalarıdır. $\mathrm{Bu}$ sonuçtan farklı olarak Orhan ve Günay (2014) çalışmalarında öğretim elemanlarının öğrencilere her yıl aynı ödevi vermesi ve ögrencilerin yeni bilgiler üretmelerine olanak sağlamamalarından dolayı 
öğrencilerin kopyalama yoluyla aynı bilgileri eklediklerini belirlemişlerdir. Yapılan çalışmaların sonuçları göz önünde bulundurulduğunda öğretim elemanlarının öğrencilerine etik ihlaller yapabilecekleri konusunda güvenmedikleri yorumu yapılabilir.

Öğretim elemanlarının çoğu uzaktan eğitim sürecinde sınıf yönetiminde sorun yaşamadıklarını belirtmişlerdir. Ortaya çıkan bu sonuç Dinçer ve Yeşilpınar Uyar'ın (2015) yapmış oldukları bir çalışmanın sonucu ile örtüşmemektedir. Yapılan çalışmaya göre eğitim fakültelerinde görev yapan öğretim elemanlarının e-öğrenme sistemlerini kullanırken öğrencilerin derse ilgisiz davranması, hazırbulunuşluklarının ve kullanılan araç ile bağ kuramamasından dolayı sınıf yönetimi konusunda sorun yaşadıklarını ifade etmişlerdir.

Uzaktan eğitim ders sürecinde genel olarak öğrencilere söz hakk1 verilmektedir. Fakat bir öğretim elemanı öğrencilerine söz hakkı vermediğini belirtmiştir. Ortaya çıkan bu sonuç öğrenciler açısından dezavantaj olarak görülmektedir. Çünkü öğrencinin derste pasif bir rol alması derse ilgilerinin azalmasına sebep olabileceği gibi öğrenim gördüğü araçla bağ kuramamasına ve konu dışı eylemlere yönelmesine sebep olabilecektir. Öğrenmede kalıcılı̆̆ın artırılabilmesi için derslerde etkileşimin bulunmas1 gerekmektedir (Ömeroğlu, 2019).

Öğretim elemanları uzaktan eğitim sürecinde sınav yapılması yerine ödev verilmesini tercih etmektedirler. Çevrimiçi eğitim ortamlarında geleneksel ve alternatif ölçme değerlendirme teknikleri uygulanabilmektedir (Erfidan, 2019). Fakat Covid-19 pandemi sürecinde Sar1 (2020), öğrencilerin gündemsel olarak stres ve kaygılara sahip olabileceklerini ve bu durumun öğrencilerin sınav notlarını etkileyebileceğini belirtmektedir. Bu nedenle bu süreçte geleneksel tekniklerin yerine alternatif ölçme değerlendirme teknikleri ile değerlendirme yapılmasının doğru bir yol olacağı düşünülmektedir. Fakat burada, süreç içindeki görevlerin ne sıklıkla verildiği ve görevlerin neleri sınadığı önem kazanmaktadır. Örneğin Balta ve Türel (2013) çevrimiçi ortamlardaki değerlendirmelerin niteliğinin artırılması için proje, performans görevleri, öz değerlendirmeler, portfolyo yapımı veya öğrencilerin birbirlerini değerlendirmelerinin haftalık olarak sağlanması durumunda öğrencinin derse katılımı açısından olumlu bir etkisinin olabileceğini ifade etmişlerdir. Yapılan bir çalışmada lisans öğrencileri uzaktan eğitim sürecinde ödevler yoluyla değerlendirilmekten memnun olduklarını belirtmişlerdir. Ancak öğrenciler ödevler için geri dönüt beklemekte ve geri dönütü önemsemektedirler (Duman, 2020). Ayrıca öğretim elemanlarının sınav yapmak yerine ödev vermeleri öğretim elemanlarının sınav hazırlamada zorlanmamaları sonucunu destekler niteliktedir.

Öğretim elemanları çevrimiçi sınavların gerçeği kısmen yansıttığını ve örgün eğitimde öğrencilerin konuyu öğrenme düzeylerinin belirlenmesinin uzaktan eğitime göre daha kolay olduğu fikrindedirler. Örgün eğitimde eğitimci ve öğrencinin aynı ortamda olmalarından dolayı eğitimci öğrenciyi gözleyebilmektedir (Gürer, Tekinarslan ve Yavuzalp, 2016). Buna ek olarak çevrimiçi sınavlarda öğretim elemanlarının ve öğrencilerin aynı ortamlarda bulunmamaları kopya çekilme ihtimalini ortaya çıkardığg için sınavlara olan güveni azalttığı düşünülmektedir (Bengtsson, 2019). Ayrıca uzaktan eğitimde öğrenci ve eğitimcinin fiziksel olarak aynı ortamda bulunmaması öğrencinin derse olan ilgisi gibi duyuşsal özelliklerini belirlemede de yetersiz kaldığı belirlenmiştir (Özyürek, Begde, Ferah Yavuz ve Özkan, 2016).

Genel olarak çevrimiçi sınav süresi öğretim elemanları tarafindan yeterli bulunmaktadır. Bunun yanı sıra sürenin uzun olduğunu düşünen öğretim elemanları sayısının da azımsanmayacak derecede çok olduğu söylenebilir. Ortaya çıkan bu sonuç öğretim elemanlarının sınav sorularını hazırlarken konuya ait kazanımları göz önünde bulundurmadıklarını, sınav sorularını kolay hazırladıklarından dolayı sürenin artabileceği veya sınav süresine ilişkin daha önceden belirlenen kurallara uyulması gerektiğinden dolayı sürenin uzun olabileceği fikrini ortaya çıkarmaktadır.

Sonuç olarak öğretim elemanlarının çoğu Adobe Connect programına kısmen hâkim olduğu ve bu programın uzaktan eğitimde kullanılmasının yeterli olduğu görüşünde oldukları belirtmişlerdir. Fakat uzaktan eğitimin tam anlamıyla uygulanabilmesi için programı kullanabilmek tek başına yeterli değildir. Özellikle pandemi sürecinde gerek alt yapı yetersizlikleri gerek donanımsal yetersizlikler uzaktan 
eğitimin uygulanmasında ki aksaklıkları ortaya çıkarmaktadır. Bu tür aksiliklerin yaşanması uzaktan eğitimin verimliliğini ve etkililiğini etkileyebilmektedir. Uzaktan eğitim sürecinde bir diğer konu öğrencilerin sınanmasıdır. Öğretim elemanları genel olarak öğrencilerine ödev vererek değerlendirmeler yapmaktadırlar. $\mathrm{Bu}$ durum öğrencilerin sadece ürün çıkarmada değil süreçte de aktif olmalarını sağlayabilir. Son olarak öğretim elemanları örgün eğitimde derslerine takviye yapılması gerektiği düşüncesindedirler. Bu şekilde uzaktan eğitim sürecinde farklı sebeplerden dolayı bilgi eksikliklerinin kapatılacağı yönünde fikir sahibi oldukları düşünülmektedir.

Yapılan çalışmanın bulguları göz önünde bulundurularak şu önerilerde bulunulabilir:

Çalışmanın sadece bir eğitim fakültesi öğretim elemanları ile yürütülmesi ve çalışılan konunun sadece bir program üzerinden değerlendirilmesi çalışmanın sınırlılıklarını ortaya çıkarmaktadır. $\mathrm{Bu}$ nedenle yapılan çalışma daha büyük çalışma grupları ve birden fazla uzaktan eğitim programına dahil edilerek tekrarlanabilir. Uzaktan eğitim sürecinde sadece bir programa bağlı kalınmaması, bu programa ek olarak alternatif programların da kullanılması gerekmektedir. Öğretim elemanlarının, uzaktan eğitim sürecinde ölçme ve değerlendirme konusunda tek bir yöntem veya tekniğe bağl1 kalmayarak farkl1 alternatif ölçme ve değerlendirme tekniklerinden faydalanmaları önerilebilir. Öğretim elemanları öğrencileriyle doküman paylaşımında etik sorunlar yaşayacaklarını düşünmektedirler. Bu durumu önlemeye yönelik dönem başında etik ihlaller yapmaları durumunda nelerle karşılaşabileceklerine dair bilgilendirmeler yapılabilir. Ayrıca ders dokümanı paylaşımında yönetim kararı ile dersler için açık erişim olan ve etik sorun oluşturmayacak dokümanların paylaşılması sağlanabilir, böyle dokümanlar hali hazırda yoksa yönetimler tarafından hazırlattırılabilir ya da telif hakkı ödenerek paylaşıma sunulabilir. Yapılan çalışma sadece bir eğitim fakültesinde yürütülmüştür. Bu durum çalışmanın sınırlılı̆̆ını ortaya koymaktadır. Bu nedenle yapılan çalışma daha büyük çalışma grupları ile tekrarlanması gelecek çalışmalarda ortaya çıkacak sonuçları daha net bir şekilde ortaya koyabilir.

\section{Araştırmacıların Katkı Oranı}

Bu çalışmada birinci yazarın $\% 40$, ikinci yazarın $\% 40$ ve üçüncü yazarın $\% 20$ oranında katkısı bulunmaktadır.

\section{Çıkar Çatışması}

Bu çalışmada çıkar çatışması teşkil edebilecek bir durum yoktur.

Açıklama: Bu çalışmanın bir kısmı Süleyman Demirel Üniversitesi Eğitim Fakültesi Birim Kalite Komisyonu'na rapor olarak sunulmuştur.

\section{Kaynaklar}

Aksu Dünya, B., Aybek, E. ve Şahin, M. (2021). Yükseköğretimde uzaktan ölçme ve değerlendirme deneyimleri: Üç devlet üniversitesinden bir örnek. Ahi Evran Üniveristesi Sosyal Bilimler Enstitüsü Dergisi, 7(1), 232-244. Doi: 10.31592/aeusbed.804016

Arkorful, V. and Abaidoo, N. (2015). The role of e-learning, advantages and disadvantages of its adoption in Higher education. International Journal of Instructional Technology and Distance Learning, 12(1), 29-42.

Bakioğlu, B. ve Çevik, M. (2020). Covid-19 Pandemisi sürecinde fen bilimleri öğretmenlerinin uzaktan $\begin{array}{lllll}\text { eğitime ilişkin görüşleri. } \quad \text { Turkish } & \text { Studies, } & \text { 15(4), } & \text { 109-129. }\end{array}$ https://dx.doi.org/10.7827/TurkishStudies.43502 
Balaman, F. ve Hanbay Tiryaki, S. (2021). Corona virüs (Covid-19) nedeniyle mecburi yürütülen uzaktan eğitim hakkında öğretmen görüşleri. Insan ve Toplum Bilimleri Araşstırma Dergisi, $10(1), 52-84$.

Barış, M. F. (2015). Üniversite öğrencilerinin uzaktan öğretime yönelik tutumlarının incelenmesi: Namık Kemal Üniversitesi örneği. Sakarya Üniversitesi Ĕ̈itim Dergisi, 5(2), 36-46. https://doi.org/10.19126/suje.38758

Barış, M. F. ve Çankaya, P. (2016). Akademik personelin uzaktan eğitim hakkındaki görüşleri. Journal of Human Sciences, 13(1), 399-413.

Başaran, M., Doğan, E., Karaoğlu, E. ve Şahin, E. (2020). Koronavirüs (Covid-19) pandemi sürecinin getirisi olan uzaktan eğitimin etkililiği üzerine bir çalışma. Academia Eğitim Araştırmaları Dergisi, 5(2), 179-209.

Bayburtlu, Y. S. (2020). Covid-19 pandemi dönemi uzaktan eğitim sürecinde öğretmen görüşlerine göre Türkçe eğitimi. $\quad$ Turkish $\quad$ Studies, $\quad 15(4), \quad$ 131-151. https://dx.doi.org/10.7827/TurkishStudies.44460

Bengtsson, L. (2019). Take-home exams in higher education: A systematic review. Education Sciences, 9(4), 1-16. https://doi.org/10.3390/educsci9040267

Bilgiç, H. G. ve Tüzün, H. (2015). Yükseköğretim kurumlarında web tabanlı uzaktan eğitim programlarında yaşanan sorunları. Açıkögretim Uygulamaları ve Araştırmaları Dergisi, 1(3), $26-50$.

Büyüköztürk, Ş. (2020). Sosyal Bilimler için Veri Analizi El Kitabı (27. baskı). Ankara: Pegem Akademi.

Büyüköztürk, Ş., Kılıç Çakmak, E., Akgün, Ö. E., Karadeniz, Ş. ve Demirel F. (2019). Bilimsel Araştırma Yöntemleri (26. bask1). Ankara: Pegem Akademi.

Cacheiro Gonzalez, M. L., Medina Rivilla, A., Dominguez Garrido, M.C. and Medina Dominguez, M. (2019). The learning platform in distance higher education: Students' perceptions. Turkish Online Journal of Distance Education, 20(1), 71-95.

Can, N. ve Köroğlu, Y. (2020). Covid-19 döneminde yaygınlaşan uzaktan eğitimin değerlendirilmesi ve eğitim emekçileri açısından incelenmesi. Madde, Diyalektik ve Toplum, 3(4), 370-381.

Chao, T, Saj, T. and Tessier, F. (2006). Establishing a quality review for online courses. Educause Quarterly, 29(3), 32-39.

Çakır, R. ve Arslan, F. (2020). Uzaktan eğitim öğrencilerinin eş zamanlı sanal sınıf ortamlarını kullanım niyetleri ile uzaktan eğitime ilişkin tutumlarının incelenmesi. Uluslararası Türk Ĕgitim Bilimleri Dergisi, 8(15), 114-133. https://doi.org/10.46778/goputeb.732565

Dinçer, S. ve Yeşilpınar Uyar, M. (2016). E-öğrenme sistemlerinin kullanımı sürecinde karşılaşılan sınıf yönetimi ile ilişsili sorunları ve çözüm önerileri. Kuram ve Uygulamada Eğitim Yönetimi Dergisi, 21(4), 453-470. Doi: 10.14527/kuey.2015.017

Duban, N. ve Şen, F.G. (2020). Sınıf öğretmeni adaylarının COVID-19 pandemi sürecine ilişkin görüşleri. Turkish Studies, 15(4), 357-376. https://dx.doi.org/10.7827/TurkishStudies.43653

Duman, S. N. (2020). Salgın döneminde gerçekleştirilen uzaktan eğitim sürecinin değerlendirilmesi. Milli Ĕgitim Dergisi, 49(1), 95-112. Doi: 10.37669/milliegitim.768887 
Erfidan, A. (2019). Derslerin uzaktan eğitim yoluyla verilmesiyle ilgili öğretim elemanı ve öğrenci görüşleri Balıkesir Üniversitesi örneği (Yüksek Lisans Tezi). Yükseköğretim kurulu Ulusal Tez Merkezi'nden edinilmiştir. (Tez no: 601493)

Eroğlu, F. ve Kalaycı, N. (2020). Üniversitelerdeki zorunlu ortak derslerden yabancı dil dersinin uzaktan eğitim uygulamasının değerlendirilmesi. Türk Eğitim Bilimleri Dergisi, 18(1), 236-265. Doi: $10.37217 /$ tebd. 683250

Erol Şahin, A. N. (2019). Atatürk İlkeleri ve İnkılap Tarihi dersinin eğitim yoluyla öğretilmesi hakkında öğretim elemanlarının görüşleri. Gazi Üniversitesi Eğitim Fakültesi Dergisi, 39(1), 477-502.

Gonu, E. and Agyepong, G. K. Q. (2016). Students' perception about quality of distance education at the university of Cape Coast, Ghana. European Journal of Business and Management, 8(15), 920 .

Gregory, M. S. J. and Lodge, J. M. (2015). Academic workload: the silent barrier to implementation of technology-enhanced learning strategies n higher education. Distance Education, 36(2), 210230. https://doi.org/10.1080/01587919.2015.1055056

Gürer, M. D., Tekinarslan, E. ve Yavuzalp, N. (2016). Çevrimiçi ders veren öğretim elemanlarının uzaktan eğitim hakkındaki görüşleri. Turkish Online Journal of Qualitative Inquiry, 7(1), 4778.

Kaçan, A. ve Gelen, İ. (2020). Türkiye'deki uzaktan eğitim programlarına bir bakış. Uluslararası Eğitim Bilim ve Teknoloji Dergisi, 6(1), 1-21.

Karadağ, E. ve Yücel, C. (2020). Yeni tip Koronavirüs pandemisi döneminde üniversitelerde uzaktan eğitim: Lisans öğrencileri kapsamında bir değerlendirme çalışması. Yükseköğretim Dergisi, 10(2), 181-192. https://doi.org/10.2399/yod.20.730688

Kara, Y. (2020). Pandemi sürecindeki öğrenci deneyimleri: Bakırköy ilçesi örneği. Avrasya Sosyal ve Ekonomi Araştırmaları Dergisi, 7(7), 165-176.

Karahan, E., Bozan, M. A. ve Akçay, A. O. (2020). Sınıf öğretmenliği lisans öğrencilerinin pandemi sürecindeki çevrim içi öğrenme deneyimlerinin incelenmesi. Turkish Studies, 15(4), 202-214. https://dx.doi.org/10.7827/TurkishStudies.44348

Karatepe, F., Küçükgençay, N. ve Peker, B. (2020). Öğretmen adayları senkron eğitime nasıl bakıyor? Bir anket çalışması. Journal of Social and Humanities Sciences Research, 7(53), 1262-1274. http://dx.doi.org/10.26450/jshsr.1868

Kırmac1, Ö. ve Acar, S. (2018). Kampüs öğrencilerinin eş zamanlı uzaktan eğitimde karşılaştıkları sorunlar. Eğitimde Kuram ve Uygulama, 14(2), 276-291. https://doi.org/10.17244/eku.378138

Koloğlu, T. F., Kantar, M. ve Doğan, M., (2016). Öğretim elemanlarının uzaktan eğitimde hazırbulunuşluklarının önemi. Açıkögretim Uygulamaları ve Araştırmaları Dergisi, 2(1), 5270 .

Orhan, F. ve Günay, A. (2014). Üniversite öğrencilerinin internet tabanlı akademik usulsüzlük nedenlerinin çeşitli değişkenlere göre incelenmesi. Ege Eğitim Dergisi, 15(1), 176-190. https://doi.org/10.12984/eed.41835

Ömeroğlu, E. (2019, 19-22 Haziran). Uzaktan eğitim sistemiyle ilgili bir araştırma: Sakarya örneği. International Congresses on Education, Sakarya Üniversitesi, Sakarya. 
https://www.erpacongress.com/upload/dosya/erpa-2019_book-of

prooceedings_15d3866b5b17ae.pdf adresinden 09.06.2021 tarihinde erişilmiştir.

Özden, M., Özdemir Özden, D. ve Biçer B. (2015). Akademik usulsüzlük: Öğretmen adaylarının görüşleri ve deneyimleri. Mersin Üniversitesi Eğitim Fakültesi Dergisi, 11(2), 506-525. https://doi.org/10.17860/efd.43453

Özgen, C. and Reyhan, S. (2020). Satisfaction, utilitarian performance and learning expectations in compulsory distance education: A test of mediation effect. Educational Research and Reviews, 15(6), 290-297. Doi: 10.5897/ERR2020.3995

Özonur, M., Kamışlı, H., Yanpar Yelken, T. ve Sancar Tokmak, H. (2019). Uzaktan eğitim öğrencilerinin Enocta öğrenme yönetim sistemi hakkında görüşlerinin incelenmesi. Mehmet Akif Ersoy Üniversitesi Eğitim Fakültesi Dergisi, 50, 283-302. Doi: 10.21764/maeuefd.407470

Özgöl, M., Sarıkaya. İ. ve Öztürk, M. (2017). Örgün eğitimde uzaktan eğitim uygulamalarına ilişkin öğrenci ve öğretim elemanı değerlendirmeleri. Yüksek Öğretim ve Bilim Dergisi, 7(2), 294-304. Doi: $10.5961 /$ jhes.2017.208

Özyürek, A., Begde, Z., Ferah Yavuz, N. ve Özkan, İ. (2016). Uzaktan eğitim uygulamasının öğrenci bakış açısına göre değerlendirilmesi. Karabük Üniversitesi Sosyal Bilimler Enstitüsü Dergisi, 6(2), 592-605.

Patricia, A. (2020). Collage students' use and acceptance of emergency online learning due to COVID19. International Journal of Educational Research Open, 99(104), 1-33. https://doi.org/10.1016/j.ijedro.2020.100011

Pepeler, E., Özbek, R. ve Adanır, Y. (2018). Uzaktan eğitim ile verilen İngilizce dersine yönelik öğrenci görüşleri: Muş Alparslan Üniversitesi örneği. Anemon Muş Alparslan Üniversitesi Sosyal Bilimler Dergisi, 6(3), 421-429. http://dx.doi.org/10.18506/anemon.345152

Sadeghi, M. (2019). A shift from classroom to distance learning: Advantages and limitations. International Journal of Research in English Education, 4(1), 80-88.

Sakarya, G. ve Zahal, O. (2020). Covid-19 pandemi sürecinde uzaktan keman eğitimine ilişkin öğrenci görüşleri. Turkish Studies, 15(6), 796-817. Doi: 10.7827/TurkishStudies.44504.

Sar1, H. (2020) Evde kal döneminde uzaktan eğitim: Ölçme ve değerlendirmeyi neden karantinaya almalıyız?. Uluslararası Eğitim Araştırmacıları Dergisi, 3(1), 121-128.

Sayan, H. (2020). Covid-19 pandemisi sürecinde öğretim elemanlarının uzaktan eğitime ilişkin görüşlerinin değerlendirilmesi. AJIT-e: Bilişim Teknolojileri Online Dergisi, 11(42), 100-122. https://doi.org/10.5824/ajite.2020.03.004.x

Serçemeli, M. ve Kurnaz, E. (2020). Covid-19 pandemi döneminde öğrencilerin uzaktan eğitim ve uzaktan muhasebe eğitimine yönelik bakış açıları üzerine bir araştırma. Uluslararası Sosyal Bilimler Akademik Araştırmalar Dergisi, 4(1), 40-53.

Sümer, M. (2016). Sanal derslere ilişkin öğrenci görüşlerinin incelenmesı. Uşak Üniversitesi Sosyal Bilimler Dergisi, 9(3), 181-200.

Şen, Ü. (2016). Yabancı dil olarak Türkçe öğretiminde uzaktan eğitim programları. Kırşehir Eğitim Fakültesi Dergisi, 17(2). 411-428. 
Şenkal, O. ve Dinçer, S. (2012). Geleneksel sınıfların uzaktan eğitim platformuna dönüştürülmesi: Bir model çalışması. Bilişim Teknolojileri Dergisi, 5(1), 13-18.

Telli Yamamoto, G. ve Altun, D. (2020). Coronavirüs ve çevrimiçi (online) eğitimin önlenemeyen yükselişi. Üniversite Araştırmaları Dergisi, 3(1), 25-34. https://doi.org/10.32329/uad.711110

Tuncer, M. ve Bahadır, F. (2017). Uzaktan eğitim programlarının bu programlarda öğrenim gören öğrenci görüşlerine göre değerlendirilmesi. The Journal of Educational Reflections, 1(2), 2938.

Tuncer, M. ve Tanaş R. (2011). Akademisyenlerin uzaktan eğitim programlarına yönelik görüşlerinin değerlendirilmesi. Ilköğretim Online, 10(2), 776-784.

Türker, A. ve Dündar, E. (2020). Covid-19 pandemi sürecinde Eğitim Bilişim Ağı (EBA)üzerinden yürütülen uzaktan eğitimlerle ilgili lise öğretmenlerinin görüşleri. Milli Ĕgitim Dergisi, 49(1), 323-342. https://doi.org/10.37669/milliegitim.738702

Türk Dil Kurumu Çevrimiçi Sözlüğü. (2021). Güncel Türkçe sözlük. https://sozluk.gov.tr/ adresinden 09.04.2021 tarihinde erişilmiştir.

Yıldız, M. (2015). Uzaktan eğitim programlarında ders veren öğretim elemanlarının uzaktan eğitime yönelik bilgi, inanç ve uygulamaları arasındaki ilişkiler (Yüksek Lisans Tezi). Yükseköğretim kurulu Ulusal Tez Merkezi’nden edinilmiştir. (Tez no: 394811)

Yıldız, V.A. (2020, 19-20 Haziran). Üniversite öğrencilerinin pandemi dönemi aldıkları eğitime ilişkin görüşleri. M., Kurt, F.A., Aksal, Z., Altınay Gazi, Y., Çerkez ve U Akçı1, (Ed), 2st International Conference on Interdisciplinary Educational Reflections (p.19-27). Near East Universtiy Conference Proceedings Book. 


\section{Extended Abstract}

\section{Introduction}

The Coronavirus Disease 2019 (Covid-19) which was stated to have emerged and began to spread in the Wuhan province of China in late 2019 and has had an impact on many fields in the world since its emergence, undoubtedly has shown one of its biggest impacts on the field of education. For this reason, educational institutions in many countries have had to adopt the distance education method in order to continue providing education during the Covid-19 pandemic. The distance education area, where various studies have been carried out before, has attracted the attention it has never seen before due to the interest it received during the Covid-19 pandemic. With the increase in distance education practice in this period, the number of researches in this field has increased and it has allowed examining the advantages and disadvantages of this method. It is thought that these advantages and disadvantages can enable the necessary preliminary preparations to fulfill the needs of users of distance education and to bring the quality of distance education to an optimal level. In this sense, this study aimed to reveal the views of the faculty of education academics towards distance education, who have been continuing their education by distance education during the Covid-19 pandemic.

\section{Method}

In accordance with the purpose of the study, the descriptive research method has been adopted in this study. The descriptive research design is the description of situation that exists in the evaluation of the person/people's behaviors and situations. Surveys through observation and questionnaires and interviews can be preferred in determining the situation ((Büyüköztürk, Kılıç Çakmak, Akgün, Karadeniz ve Demirel, 2019, s. 24). Participants which are 35 academics working in the faculty of education in a state university in Turkey were selected by using the convenience sampling method. In the study, the the descriptive research design was preferred. Data were collected with the help of an online questionnaire prepared by the researchers. Gathered data were analyzed by using descriptive statistics such as frequency and percentage tables.

\section{Findings}

The findings of the study are grouped under five categories. The first of these categories is "academics' evaluations about the use of Adobe Connect software". It was determined that more than half of the academics were able to use the Adobe Connect program. A close number of academics stated that the use of Adobe Connect program in distance education is "sufficient" or "partially sufficient". Very few academics mentioned that the program was insufficient.

The second category is "academics' evaluations regarding the implementation of distance education". Within the scope of this category, academics expressed "telecommunication" and "lack of experience" most as the obstacles they experienced in distance education. On the other hand, minority of the academics participated in the study stated that they did not encounter any obstacle.

While more than half of the academics think distance education is "partially effective", the number of academics who think it is "effective" and "ineffective" is almost the same. Few academics consider distance education being efficient. The number of academics who think that distance education is "partially efficient" or "not efficient" is quite high. Academics stated that they prefer "verbal expression" mostly, and "solving questions" and "other methods" least in distance education. Academics generally found the duration of lessons in distance education "sufficient" and "partially sufficient". The number of academics who think that ethical problems may or may not be experienced in terms of document sharing are close to each other. 
The fourth category is "academics' evaluations about classroom management during distance education". Most of the academics stated that they had problems in classroom management. Only a few academics stated that they did not have any problems in classroom management.

The fourth category is "academics' evaluations on the distance education examination system". While it was determined that most of the academics evaluated their students through 'homework' and 'project', it was determined that very few academics used 'offline exams' and 'process-based assessment' methods. Additionally, the number of academics who think that successful students cannot reflect their success in the distance education is very low. While it was determined that a great majority of the academics found the duration of the exam as "sufficient" and "partially sufficient", it was determined that an academic thought the exam duration was "insufficient". Most academics stated that they prefer online exams. However, an academic who stated preferring written exams shared that the process of preparing a written exam for distance education is hard.

The fifth category is "academics' evaluations about the post-distance education process". This category consists of the opinions of the academics regarding supplementary education after distance education. Most of the academics stated that supplementary education after distance education is partly needed. The number of academics who stated that there is a need or no need for supplementary education after distance education is equal.

\section{Conclusion, Discussion and Recommendations}

It has been found that the majority of the academics have mastered the Adobe Connect software, the Adobe Connect program is sufficient in distance education the biggest obstacle in the implementation of distance education is the lack of infrastructure. This result is supported by the literature (Y1ldiz, 2020). Problems such as lack of infrastructure, experience, and documentation in distance education can affect the efficiency and effectiveness of distance education. When the studies conducted through distance education are examined; it is known that the distance education process is effective and efficient if it is carried out correctly (Özonur, Kamışl1, Yanpar Yelken ve Sancar Tokmak, 2019). This situation reveals the idea that distance education can be successful if both infrastructure and hardware deficiencies are eliminated so that it can be carried out efficiently. However, contrary to this situation, there are studies stating that the efficiency of distance education is insufficient (Balaman ve Hanbay Tiryaki, 2021). It is thought that the reason for this situation may be both ethical problems and habits to face-to-face education. Academics generally make evaluations by giving homework to their students. Thus, students can be enabled to stay active in the process. For instance; Balta ve Türel (2013), determined that students' projects, performance tasks, self - evaluations, portfolio preparation of providing students to evaluate each other on a weekly basis in online learning environments positively affect the student's participation in the course. Finally, academics think that supplementary education should be offered in formal education. When the results are taken into consideration, suggestions can be given in order to maximize the quality of distance education such as; software-oriented training can be given before the implementation of the software planned to be used in distance education because even though they are few in number, there are academics who have difficulties in mastering the distance education software used in the institution; different alternative assessment and evaluation techniques can be used in distance education; academics can be informed about the consequences of ethical issues related to sharing copyrighted documents at the beginning of the semester, additionally, academics can be encouraged to share open-access documents that won't cause any ethical issues, lastly, documents that won't cause any ethical issues in sharing with students can be produced by the administrations or documents can be shared after getting the copyrights in order to prevent these issues because academics stated their concerns about encountering ethical issues in sharing documents with their students. Similar studies can be carried out with more participants in various private and public universities that use different software to investigate different distance education experiences. 